\title{
ПРАВОВІ АСПЕКТИ ВІДНЕСЕННЯ СЕКС- ПРАЦІ (ПРОСТИТУЦІї) ДО ЛЕГАЛЬНИХ ВИДІВ ЕКОНОМІЧНОї ДІЯЛЬНОСТІ
}

\section{ГАБРЕЛЯН Андрій Юрійович - аспірант Київського міжнародного університету}

DOI:10.32782/EP.2020.1.7

Стаття присвячена правовим аспектам віднесення проституиї до легальних видів економічної діяльності. Встановлено, що явище проституциї (надання сексуальних та/або інтимних послуг, секс-праия) потребує легалізачіӥ з дотриманням певних особливостей задля захисту прав людини, забезпечення належного рівня сочіальних $i$ правових гарантій для надавачів послуг та здійснення державного контролю за наявною сберою суспільних відносин, яка наразі тісно пов'язана із злочинною діяльністю.

Ключові слова: проституиія, секспраия, легалізачія проституцї, регулювання проституиї, інтимна послуга, сексуальна послуга, секс-послуги

\section{Вступ}

Тема легалізації проституції вже давно дискутується в українському суспільстві. Проте єдиний нормативно-правовий акт, покликаний врегулювати на державному рівні сферу надання послуг сексуального та інтимного характеру, а також захистити права осіб, які добровільно обрали для себе сферу проституції у якості економічної діяльності (законопроект № 3139, спрямований на врегулювання проституції та діяльності секс-закладів [7]), був знятий з розгляду. Окрім того, згаданий законопроект містив значні змістовні прогалини та недоліки законодавчої техніки. При аналізі цього законопроекту складається враження, що він був внесений для розгляду у Верховну Раду України з єдиною метою - зрозуміти, як поставиться українське суспільство до пропозиції парламентарів щодо легалізації проституції. Проте, в будь-якому випадку, нічого кращого на законодавчому чи підзаконному рівні до теперішнього часу в Україні запропоновано не було.

Тому метою даної статті є спроба визначити дієвий механізм включення проституції до легальних видів економічної діяльності задля забезпечення захисту прав осіб, залучених до такої діяльності, зменшення рівня злочинності у сферах, дотичних до проституції (наприклад, торгівля людьми, дитяча проституція, торгівля наркотиками тощо), створення ефективного державного контролю за сферою надання сексуальних та інтимних послуг, а також детінізації доходів, які на сьогодні вважаються злочинними, шляхом їх оподаткування.

\section{Виклад основного матеріалу}

На нашу думку, регулювання проституції в нашій державі повинно містити низку особливостей, які будуть розглянуті нами далі.

Так, одним із найважливіших цензів вважаємо віковий. Доцільним видається встановлення мінімального віку як для клієнтів, так і надавачів послуг (незалежно від статі) на рівні 21 року. Незважаючи на встановлений Цивільним кодексом України 18-річний вік як окремий критерій набуття повної дієздатності [9], на нашу думку, варто врахувати помилки ФРН під час легалі- 
зації проституції, де встановлення мінімального віку для надання інтимних послуг на рівні 18 років викликало негативну реакцію суспільства, попри позитивне або нейтральне ставлення до легалізації проституції в цілому [2]. У свою чергу обмеження щодо встановлення максимальної вікової межі не є доцільним.

Після здобуття повної середньої освіти та певного профорієнтаційного періоду особа, на власний розсуд та за вільним волевиявленням, може обрати надання сексуальних та/або інтимних послуг у якості різновиду економічної діяльності. Забезпечення додержання такого волевиявлення під час вибору фізичною особою секс-праці (проституції) в якості економічної діяльності підтверджується поданою у встановленому порядку «заявою про державну реєстрацію фізичної особи підприємцем». До власноруч написаної (або поданої реєстратору за допомогою електронного цифрового підпису) заяви особа, яка бажає здійснювати підприємницьку діяльність у сфері секспослуг, повинна докласти копію паспорта (для ідентифікації особи та, зокрема, для підтвердження відповідного віку).

Наступним обмеженням є необхідність отримання ліцензії на діяльність у сфері секс-послуг. Щодо секс-праці, на нашу думку, повинні виконуватися всі положення Закону України «Про ліцензування видів господарської діяльності» від 02.03.2015 p. № 222-VIII [5], які не суперечитимуть положенням спеціального Закону. До переліку документів, що будуть подаватись до органу ліцензування для отримання необхідної ліцензії для здійснення діяльності у сфері секс-послуг, повинна обов'язково входити довідка, в якій відображатиметься інформація про стан здоров'я (відсутність ВI// СНІД, гепатиту та інших захворювань, які можуть передаватись статевим шляхом). Без надання такої довідки фізична особапідприємець не зможе отримати первинну ліцензію на здійснення підприємницької діяльності у сфері секс-послуг.

До того ж, ліцензія повинна мати обмежений термін дії для унеможливлення зловживань або надання недостовірної інформації про стан здоров'я підприємця (iз обов'язком іï безкоштовного поновлення, наприклад, кожні три місяці). Для поневолення ліцензії особа повинна буде знов надати медичну довідку встановленого зразка щодо відсутності у неї захворювань, які можуть передаватись статевим шляхом.

До причин дострокового анулювання ліцензії секс-працівників можуть бути віднесені наступні:

- порушення ліцензійних умов (особливо стосовно не проходження медичного огляду вчасно, подання недостовірної інформації про стан здоров'я);

- припинення надання сексуальних та/ або інтимних послуг особою (шляхом припинення діяльності фізичної особи-підприємця чи юридичної особи або просто вибір іншого виду економічної діяльності);

- здійснення особою насильницького чи пов'язаного з незаконним обігом наркотиків кримінального проступку;

- примушування інших осіб до надання сексуальних та/або інтимних послуг (за аналогією із укладенням цивільного правочину під впливом насильства чи тяжкої обставини).

Що ж стосується юридичних осіб, які надають послуги сексуального та/або інтимного характеру (секс-закладів), то вони отримують безстрокову ліцензію.

Зауважимо, що надання сексуальних та/ або інтимних послуг без чинної ліцензії не буде визнаватись законною підприємницькою діяльністю та міститиме в собі ознаки адміністративного правопорушення, відповідальність за яке передбачено ст. 164 КУпАП.

Окремо варто зазначити, що надання інформації про стан здоров'я третім особам певною мірою порушуватиме забезпечувану Цивільним кодексом України від 16.01.2003 р. № 435-IV [9] та Законом України «Основи законодавства України про охорону здоров’ я» від 19.11.1992 р. № 2801XII таємницю про стан здоров'я [4]. Однак надання такої інформації, незважаючи на їі конфіденційність, необхідне для здійснення підприємницької діяльності на засадах добросовісності, для унеможливлення заподіяння моральної шкоди іншим особам, а також для виключення кримінальної відповідальності секс-працівника за умисне за- 
раження особи, наприклад, вірусом імунодефіциту людини (ст. 130 КК України [3]).

Для забезпечення захисту прав осіб, які надають сексуальні та/або інтимі послуги, а також дотримання конституційного принципу рівності прав і свобод людини, ми вважаємо за необхідне надати право цим особам вимагати (за власним бажанням) у клієнтів інформацію про стан їх здоров'я (у належній формі та 3 обмеженим терміном діiі). Ненадання такої інформації може бути визнано безумовною підставою для відмови у наданні сексуальних послуг. Проте дане право повинно стосуватись лише сексуальних послуг, інтимні послуги повинні надаватись без даного обмеження.

Цікавою є позиція, що підставою для відмови у наданні сексуальних послуг має визнаватись і вчинення насильницького та (або) статевого злочину в минулому (судимість за який не знято або не погашено у встановленому законодавством порядку). Проте, на нашу думку, ця позиція є помилковою, крім того, вимогу буде важко реалізувати на практиці, не вимагаючи у клієнта довідки про несудимість.

Окрім індивідуальної підприємницької діяльності, надання сексуальних та/або інтимних послуг (у випадку їх легалізації) може здійснюватися і через найманих працівників (наприклад, для комерційних підприємств - секс-закладів). Нормативному регулюванню в такому випадку підлягає взаємодія між секс-закладом (у певній передбаченій законом організаційно-правовій формі) і секс-працівником, який вільно обирає для себе діяльність у сфері надання сексуальних та/або інтимних послуг.

Працівники секс-закладів повинні або працювати за трудовим договором, або укладати цивільно-правовий договір.

Щодо трудового договору, то у випадку надання сексуальних та/або інтимних послуг через секс-заклади, саме роботодавець повинен дбати про дотримання всіх соціальних та трудових гарантій (відпустки, оплата тимчасової непрацездатності тощо), оновлення медичних довідок встановленого зразка щодо відсутності у працівників захворювань, які можуть передаватись ста- тевим шляхом, здійсненні необхідних податкових відрахувань та ін.

У разі використання цивільно-правового договору необхідно пам'ятати про несистемний характер надаваних послуг, визначений термін дії договору, а також те, що навіть вибір часу та місця виконання договору, якщо останні не є істотними умовами, здійснюються стороною цивільно-правового договору (виконавцем) на власний розсуд, інакше для роботодавця (замовника послуг) можливі негативні наслідки в результаті проведення планової чи позапланової перевірки представниками Державної фіскальної служби України або Державної служби України з питань праці.

Особи, що надають сексуальні та/або інтимні послуги, повинні мати можливість відмови від надання послуг, відповідно до цивільно-правових норм, про що повинно бути зазначено в договорі чи публічній оферті (наприклад, у випадку, коли клієнт (потенційний отримувач послуг) не надав інформації про стан свого здоров'я (відсутність хвороб, що передаються статевим шляхом, ВІ $\mathcal{\lambda} / \mathrm{CHIД} \mathrm{тощо),} \mathrm{перебуває} \mathrm{у} \mathrm{ста-}$ ні алкогольного (наркотичного чи токсичного) сп'яніння тощо.

Окремо слід зазначити про гарантії соціального і правового захисту для осіб, які надають сексуальні та/або інтимні послуги. Легалізація секс-послуг дасть змогу забезпечити соціальний захист для надавачів таких послуг, виплату пенсій через державні та недержавні (за бажанням особи) пенсійні фонди, оплату тимчасової непрацездатності тощо.

Важливо також забезпечити державну й недержавну (з боку об'єднань, товариств, асоціацій чи інших громадських організацій) підтримку особам (незалежно від статі), які бажають припинити надання секспослуг та здійснити перекваліфікацію своєї професійної діяльності. Така підтримка в перекваліфікації не може вважатися чимось винятковим, що застосовується лише для осіб, які повинні «реабілітуватися» після надання сексуальних та/або інтимних послуг. Навпаки, зміна діяльності здатна мотивувати особу, убезпечити від «професійного вигорання» (яке, на жаль, не є рідкісним 
явищем серед представників, наприклад, медичних або правничих професій).

Особам, які бажають змінити професію, набути нових навичок чи займатися іншим видом економічної діяльності держава (через Державну службу зайнятості та їі осередки на місцях) повинна надавати більше можливостей отримати додаткову чи основну спеціальність (шляхом пропонування дистанційного навчання із підтверджуючим документом, збільшення розміру допомоги на відкриття власної справи, розширення переліку професій (спеціальностей), доступних для опанування тощо).

Зважаючи на об'єктивно необхідний ускладнений процес початку надання сексуальних та/або інтимних послуг (на легальних засадах), необхідним (принаймні, на етапі виходу сексуальних та інтимних послуг із сектору тіньової економіки та злочинної діяльності) є посилений контроль за дотриманням усіх вимог.

3 метою уникнення зловживань, тиску чи інших неправомірних дій, які можуть порушити права осіб та виділити серед усіх підприємців тієї групи, яка буде надавати секс-послуги, вважаємо за доцільним віднести діяльність по наданню послуг сексуального та/або інтимного характеру до існуючого КВЕДу 96.04 «Діяльність із забезпечення фізичного комфорту». Такий крок дозволить спростити ведення бізнесу та комунікацію 3 місцевими реєстраційними та контролюючими органами.

Виокремлення послуг сексуального та інтимного характеру в окремий КВЕД, на нашу думку, буде вимагати зміни загальної процедури реєстрації фізичної особи, що $\epsilon$ на сьогодні недоцільно як з економічної так, і з практичної точок зору.

Водночас, на початковому етапі легалізації секс-праці потрібен певний пільговий період, коли особа, що вирішила легалізувати свою діяльність, яку здійснювала до набуття чинності спеціального закону, що легалізує секс-працю, не буде нести відповідальності за попередні дії, що підпадають під легалізацію, у випадку отримання нею всіх необхідних дозволів (наприклад, в межах річного терміну після набуття чинності законодавчим актом, який буде спря- мований на регулювання таких відносин). Варто зауважити, що такий підхід цілком співвідноситься із позицією, висловленою Конституційним Судом України про те, що «справедливе застосування норм права - 6 передусім недискримінаційний підхід, неупередженість» [8].

Оскільки разом із гарантіями соціального і правового захисту у надавачів послуг виникають обов'язки зі сплати податків, зборів чи інших обов'язкових платежів, визначених Податковим кодексом України від 02.12.2010 р. № 2755-VI (можливо, також обов'язок страхування життя та здоров'я, на розсуд законотворця) їх виконання потрібно контролювати (шляхом подання декларацій, проведення виїзних та невиїзних перевірок тощо). Цими питаннями займається Державна фіскальна служба України, як гарант забезпечення рівності всіх видів та форм підприємницької діяльності. Додержання вимог ліцензування, на нашу думку, може бути покладено на Управління ліцензування МВС України.

Після надання необхідних соціальноправових гарантій надавачам сексуальних та/або інтимних послуг, легалізації секспраці та остаточного унормування таких відносин доцільним видається закріпити більш жорсткі заходи відповідальності за надання сексуальних та/або інтимних послуг без отримання належної ліцензії та проходження всіх необхідних медичних оглядів.

У будь-якому випадку перед ухваленням будь-якого конкретного механізму легалізації секс-праці важливим 6 проведення експертних обговорень за участю, перш за все, фахових правозахисників для напрацювання територіальної моделі такої легалізації - чи буде це нормативно-правовий акт, що діє на всій території України, чи спершу легалізація почнеться як різновид пілотного проекту - на територіях певних міст (областей), як це відбувалося, наприклад, з медичною реформою. Можливий і третій шлях - у випадку запровадження певних рамкових правил нормативно-правовим актом 3 подальшою деталізацією правил надання сексуальних та інтимних послуг рішеннями міських (обласних) рад. Однак у випадку обрання такого шляху законодавець пови- 
нен передбачити і запобігти всім ризикам такого місцевого регулювання (наявність корупційних схем, нівелювання правового та соціального захисту надавачів сексуальних й інтимних послуг та їх клієнтів, протиріччя у нормативному регулюванні тощо).

\section{Висновки}

Явище проституції (надання сексуальних та інтимних послуг, секс-праця) потребує легалізації на рівні законодавчих та підзаконних актів задля захисту прав людини, забезпечення належного рівня соціальних і правових гарантій для надавачів послуг (незалежно від їх статі) та здійснення державного контролю за існуючою сферою суспільних відносин, яка наразі тісно пов’язана із злочинною діяльністю. На початковому етапі легалізації секс-праці можна обрати певну територіальну модель законного надання секс-послуг (за аналогією із пілотним проектом медичної реформи в Україні). Надання сексуальних та інтимних послуг потребує обгрунтованих обмежень (віковий ценз, відповідний стан здоров'я, відсутність судимості тощо).

Після легалізації надання сексуальних та інтимних послуг може здійснюватися як фізичними особами-підприємцями, так і шляхом укладання договорів із юридичними особами. Така діяльність обов'язково потребуватиме ліцензування (із умовою проходження медичного обстеження мінімум кожні три місяці). Повинен існувати також перелік вимог для користувачів сексуальних та інтимних послуг (незалежно від їх статі). Надання секс-послуг без ліцензії чи за наявності недійсної ліцензії повинно тягнути за собою настання адміністративної відповідальності. Крім того, необхідне запровадження відповідальності за надання сексуальних послуг без використання засобів контрацепції бар'єрного типу (презервативів).

Зауважимо, що отримання державою нового джерела наповнення бюджету дасть змогу забезпечити необхідний обсяг соціальних і правових гарантій для надавачів сексуальних та інтимних послуг, виведе проституцію із сектору тіньової економіки та нівелює вплив на неї суб’єктів злочинних діянь.

\section{Лiтература}

1. Кодекс законів про працю України від 10.12.1971 р. № 322-VII. Відомості Верховної Ради, 1971. Додаток до № 50. Ст. 375

2. Конрад Н., Фельден Е. Проституція в Німеччині - легально, але дуже небезпечно. URL: https://p.dw.com/p/30OhH (дата звернення: 22.01.2019)

3. Кримінальний кодекс України від 05.04.2001 р. № 2341-III. Відомості Верховної Ради Украӥни, 2001. № 25-26. Ст. 131

4. Основи законодавства України про охорону здоров'я: Закон України від 19.11.1992 р. № 2801-XII. Відомості Верховної Ради Украӥни, 1993. № 4. Ст. 19

5. Про ліцензування видів господарської діяльності: Закон України від 02.03.2015 р. № 222-VIII. Відомості Верховної Ради Украӥни, 2015. № 23. Ст. 158

6. Про затвердження Положення про Державне агентство з питань електронного урядування України: Постанова Кабінету Міністрів України від 01.10.2014 р. № 492. Дата оновлення: 18.07.2018. URL: https:// zakon.rada.gov.ua/laws/show/v015p710-04 (дата звернення: 25.09.2018)

7. Проект Закону про регулювання проституції та діяльності секс-закладів від 18.09.2015 p. № 3139. Дата оновлення: 12.10.2015. URL: http://w1.c1.rada.gov.ua/ pls/zweb2/webproc4_1?pf3511=56559 (дата звернення: 10.02.2018)

8. Рішення Конституційного Суду України у справі за конституційним поданням Верховного Суду України щодо відповідності Конституції України (конституційності) положень статті 69 Кримінального кодексу України (справа про призначення судом більш м'якого покарання) від 02.11.2004 p. № 15-рп/2004. Дата оновлення: 02.11.2004. URL: https://zakon.rada.gov. ua/laws/show/v015p710-04 (дата звернення: 10.02.2018)

9. Цивільний кодекс України від 16.01.2003 р. № 435-IV. Відомості Верховної Ради Украӥни, 2003. №№ 40-44. Ст. 356 


\section{Адміністративне право}

Gabrelyan Andrey Yuryevich $\mathrm{PhD}$ student

Kyiv International University Kyiv, Ukraine

\section{MECHANISM OF INCLUSION OF SEX- LABOR (PROSTITUTION) TO LEGAL TYPES OF ECONOMIC ACTIVITY}

Introduction. The issue of the legalization of prostitution in Ukrainian society has become relevant a long time ago and still enjoys the increased attention of lawmakers and the public, requiring, however, further scientific research on interaction with the priority of protection of human rights and freedoms, the principle of the rule of law and freedom of enterprise.

Purpose. The purpose of the article is to attempt to identify an effective mechanism for the inclusion of prostitution in legal economic activities in order to protect the rights of persons involved in such activities, to create effective state control over the sphere of sexual and intimate services.

Results. While prostitution remains outside legal influence and is not limited by state control, except for budget losses due to its non-taxation, it is accompanied by other negative phenomena: corruption, intimidation, unlawful influence on persons, money laundering, illegal foreign trade operations, etc. Only effective work of the controlling bodies can counteract this complex. And the legalization of prostitution will make it impossible for these negative phenomena to exist, or at least minimize them because of the need, for example, declaring income, creating a special tax, having separate tax oversight, increasing accountability, and more. In the case of prostitution, it will acquire all the attributes of entrepreneurial activity, and persons involved in prostitution as providers or consumers of services, regardless of gender, will be able to enjoy the full range of guarantees provided by the rules of civil, labor and criminal law.

Conclusion. The phenomenon of prostitution requires legalization at the level of legislation and regulations in order to protect human rights, to ensure an adequate level of social and legal guarantees for service providers and to exercise state control over the existing sphere of public relations, which is now closely linked to criminal activity. At the initial stage of the legalization of sex work, one can choose a territorial model of the legal provision of sex services. The provision of sexual and intimate services requires reasonable restrictions (age, health, lack of criminal record, etc.).

Key words: prostitution, sex work, legalization of prostitution, regulation of prostitution, intimate service, sexual service, sex services 